\title{
ONESNAŽENJE IN PROSTORSKI RAZVOJ SLOVENIJE
}

\author{
Dusan Plut*
}

IZVLEČEK

UDK 911.3:504.054(497.12)

Degradacija pokrajinotvornih sestavin Slovenije se stopnjuje in dobiva tudi ekonomske in zdravstvene razsežnosti. Neobhodni so temeljiti preventivni in kurativni ukrepi, predvsem pa ckološko primerno prestrukturiranje gospodarstva.

\section{ABSTRACT}

UDC 911.3:504.054(497.12)

POLUTION AND REGIONAL DEVELOPMENT OF THE SLOVENIA

The degradational processes have within Slovenia reached europe's highest levels. They impact already the economy of the society and the health of the people. There is a need for an imidiate preventive and curing actions whithin which the economy must be restructured.

Civilizacijo ob koncu 20. stolet ja se vedno onesnažuje kolonizatorska mentaliteta in ravnanjc. Antropogeno pospescvanje snovno-energetskih tokov s pozitivno povratno zvezo vnasa $v$ pokrajinske ekosisteme vse vec nepovratnih sprememb in skod (Odzuck, 1982). Zarisujejo se prvi, nedvoumni znaki plaretarnih razsežnosti polucijskih obremenitev, ki utegnejo ob nespremenjenih obrazcih dela in bivanja ogroziti biološo - ckološke temclje cloveštva (Odum, 1971). Med planetarnimi omejitvami (prostor, rodovitna zemlja, surovine, energija, samoxistilne zmogljivosti) postaja onesnaževanje okolja najbolj pereð omejitveni dejavnik materialne dejavnosti človeštva. Tudi socializem sc je nekritixno ujel $\mathrm{v}$ entropijsko zanko in $\mathrm{z}$ inertnim vztrajanjem na modelu kclixinske rasti še pospeßil degradacijsko - entropijske procese.

Degradacijska kriza Slovenije je odraz splošne krize v družbi, neposredno pa je poslcdica napačnih razvojnih usmeritev (Vuga, 1989). Tako Jugoslavija kot Slovenija sta s tujimi krediti in inertno razvojno strategijo "prespali" energetsko vzpodbujeno prestrukturiranje gospodarstva $v$ začctku sedemdesetih let. Nadaljevalo se je vlaganje $v$ cnergetsko - surovinsko zahtevne industrijske panoge, centraliziranc encrgetske objekte (TE, JE), velike prašixje farme in agrokombinate. Pregreta industrializacija je se naprej potckala ob stihijski deagrarizaciji, odseljevanju prebivalcev iz hribovitih in robnih pokrajin, opušcanju obdelovalne zemlje. Vrsta njenih pozitivnih uxinkov je zaradi vztrajanja na razvojno in ekolosko preživelem razvojnem modclu postopoma zbledela in prixela pridobivati negativne ekonomske, socialne, energetske, entropijske in ckoioske uxinke.

* Dr., univ. doc., Oddelek za geografijo, Filozofska fakulteta, 61000 Ljubljana, Aškerčeva 12, YU. 
Tako se danes sooxamo s tudi finaneno zahtevno preobremenitvijo okolja ob 5500 dolarjih družbenega proizvoda in ob gospodarski stagnaciji ali celo nazadovanju, na dnu razvojne krivulje. Zgolj za sanacijo teh najbolj perecih degradacijskih problemov ( కestih letih vložiti milijardo dolarjev oziroma približno dvoletno neto akumulacijo slovenskega gospodarstva glede na leto 1988 . Vec kot Stiridesetletno negiranje pokrajinsko - ekoloskih in surovinsko - energetskih vidikov neizprosno ter ja visok finančni davek. Nadaljevanje po isti poti pa zanesljivo prinasa spiošen narodnogospodarski in degradacijski zlom.

Poděrtati je potrebno, da enaki viri in kolixine onesnaževanja ustvarjajo ob razlǐ̌nih fizixnogeografskih osnovah tudi razlix̌no obcutno in razsežno degradacijo okolja. Raznovrstne naravne znacilnosti slovenske pokrajine in fizienogeografska struktura regionalnih ekosistemov Slovenije pomembno vplivajo na obseg, dinamiko in intenzivnost degradacijskih procesov. Upravið̌eno namrex poudarjamo, da je geografsko okolje $v$ Sloveniji $v$ celoti in predvsem v nekaterih obmozjih pokrajinsko bolj degradirano kot bi priðakovali glede na cmisijo skodljivih snovi, pa tudi glede na doseženo stopnjo materiainega standarda ter industrijskega in urbanega razvoja. Gre torej za oxitna nesorazmerja med onesnaževanjem in onesnažcnostjo, med emisijo in imisijo (Radinja, 1979).

Zaradi vztrajanja pri kolixinskem modelu razvoja ter v celoti se pri vedno skromnem deiežu Cišcenja se koliðina odpadkov (cmisij) še naprej veða. V obdobju 1970 - 1985 se degradacijski procesi iz 50 . in 60 . Iet niso ustavili. Pojavila se je t.i. druga generacija onesnaževalcev s problemi odlaganja posebnih odpadkov in nerešenim vprašanjem končnega odlaganja vsch vrst radioaktivnih odpadkov.Prostorsko-ckološki konflikti so se zaostrili do prvih znakov sinenergetskih učinkov v najbolj degradiranih regijah (Mežiška dolina, Šaleß̌ka dolina, Ccljska kotlina, Ljubljanska kotlina, Zasavje). Slovenija se kot celota vztrajno približuje vse bolj onesnaženim evropskim regijam. Zelo kritiæna je splošna onesnažcnost zraka, saj se emisije Łe kar naprej povecujejo. Tako gre letno v ozracje 250.000 ton $\mathrm{SO}_{2}$ (Sajko, 1988, s. 164),. Po kolicini §kodljivega $\mathrm{SO}_{2}$ na prebivalca $(131 \mathrm{~kg})$ se Slovenija uvršca v sam vrh najbolj obremenjenih evropskih dežel. Zgolj iz domasčih virov naj bi na $\mathrm{km}^{2}$. letno odpadlo povpreěno 10 ton ali $10 \mathrm{~g} / \mathrm{m}^{2}$, kar je $5 \mathrm{~g} / \mathrm{m}^{2}$ žvepla (Radinja, 1988). Dosedanje analize pa opozarjajo, da v primerjavi $\mathrm{z}$ avtohtonimi emisijami $\mathrm{SO}_{2}$ vsebujejo naše padavine 2,5 -krat več žvepla $\left(11 \mathrm{~g} / \mathrm{m}^{2}\right)$. Če upoštevano vrednost primerjamo $\mathrm{z}$ vrednostmi drugje po Evropi, vidimo, da se Slovenija uvrక̌̌a med ozemlja, ki prejemajo dalę̌ najveðje kolicine žvepla. Takšne količne naj bi v Evropi prejemala le tri obmoxja, znana po klasični, a intenzivni industrijsko - energetski strukturi: Češka s Šlonskim in Doneško obmoxje. Vzroki za takšne kolicine žvepla, ki padejo v Sloveniji so relativno velike lastne emisije $\mathrm{SO}_{2}$, njene pokrajinske poteze (dolinsko - kotlinska lega virov emisij, humidnost) in neugodna lega Slovenije glede na prevladujoč usmerjenost onesnaženih zračnih gmot. Le-te dotekajo bodisi iz Srednje, Zanodne pa tudi Mediteranske Evrope, še 
posebno iz bližnje, moxno industrializirane Severne Italije (Radinja, 1988, s. 10-11).

V letu 1975 se je $v$ obmoxja onesnaženosti zraka (IV. in III. območje) uvrš̌alo 28 nasclij, leta 1987 pa žc 44 nasclij, v katerih živi veð kot Cetrtina prebivalcev Slovenije.

Raziskave stanja liß̌ajske vegetacije (analize dr. F. Batixa) dokazujejo, da je onesnažcnost okolja splošna, saj je le na $1 \%$ popisne ploskve ugotovljena bujna lišajska vegetacija. Onesnaženost zraka je poglavitni znak, da se uvršcamo v skupino dežel z najve jimi poškodbami gozdov (Šolar et al. 1989). Po rezultatih popisa iz leta 1987 je ugotovljena $43,7 \%$ poßkodovanost drevesnih vrst (leta $1985-54,6 \%$, vendar so izboljకave vezane le na 1. stopnjo ogroženosti), v Sloveniji pa imamo le š 5,9\% zdrave jelke in $21,8 \%$ zdrave smreke, v GG Nazarje in Slovenj Gradec pa skoraj $80 \%$ poకkodovanega gozda $\mathrm{z}$ visokim deležem moxno poškodovanih ali celo unix̌enih dreves (Čampa - Žonta, 1989). Poskodbe dedne snovi (biogenetska indikacija) pri smreki kažejo na skrajño zaskrbljujočo prihodnost gozda, saj nastopajo na skoraj $70 \%$ celotnega slovenskega ozemlja poskodbe tretjega in cetrtega razreda genetske poskodovanosti. Bioindikator ji po mnenju Druskoviðeve et al. (1989) nedvomno potrjujejo, da so pokrajinski ekosisiemi Slovenije na zgornji meji zmogljivosti (odsotnost liక̌jev, poškodovanost genetskega materiala, ogroženost rastlinskih vrst).

Med kolixinsko bogatimi vodnimi viri se različne stopnje onesnažcnosti pojavljajo že pri vseh skupinah, saj so vse bolj ogroženi izviri (zlasti kraski), talna voda, naravna in unetna jezera ter Severni Jadran. Zaradi tradicionalnih fekainih voda in povečanega kemixncga zastruppljanja šc narašajo težave $\mathrm{z}$ varovanjem kraskih vodnih virov, obenem pa zamujajo prizadevan ja za cišcenje odpadnih voda (Habič, 1989). Slabša se tudi kakovost talne vode (Dravsko polje, Sorక̌ko polje, Brežiłko-krško polje, Ljubljansko polje, Ponurje), ki je skupaj z vodani izvirov osnovni vir oskrbe s pitno vodo. S toksix̌nimi snovmi je onesnažena že globalno ležeča talna voda Sorłkkega in Kranjskega polja (Zupan, 19S9). Narascujoca splošna cutrofikacija Scvernega Jadrana, obCasni pojavi katastrofainih "cvetenj rastlinskega planktona" in "rde`e plime", splošno naraక̌̌anje koncentracij nekaterih toksiěnih kovin in pesticidov $\mathrm{v}$ morskih organizmih, so nedvoumni znaki rabe in zlorabe severnojadranskega morskega okoIja. Ccloten Severni Jadran se glede na breme onesnažcvanja in posledičnih degradacij okolja uvršča med najoolj prizadeta obmox̌ja svetovnega oceana (Štirn, 1989, s. 100).

Najhuje pa so onesnažene vse vexje in vexina manjših slovenskih rek. Skupno breme njihovega organskcga onesnaževanja že presega 10 milijonopv populacijskih enot (PE), naraša pa onesnaženje s toksixnimi snovmi. V letu 1983 je znasala poraba pitne vode za vodno oskrbo gospodin.jstev 154 milijonov $\mathrm{m}^{3}$ oziroma $223 \mathrm{l} / \mathrm{preb}$./dan, poraba pitne in tehnoloske vode $\mathrm{v}$ industriji in ostalih dejavnostih pa 267 milijonov $\mathrm{m}^{3}$. Skupna poraba iz javnih crpališ je torej znasala 420 milijonov $\mathrm{m}^{3}\left(13,5 \mathrm{~m}^{3} / \mathrm{s}\right)$ oziroma $620 \mathrm{l} / \mathrm{preb}$ /dan. Zaradi se vedno skromnega uxinka sicer vse stevilnejsih 
cistilnih naparav se $80-90 \%$ uporabljene vode vraða $v$ vodne vire neprecišene. Predvsem se iz rek za potrebe hlajenja naxrpa se dodatnih 680 milijonov $\mathrm{m}^{3}$ vode $\left(22 \mathrm{~m}^{3} / \mathrm{s}\right)$. Tako se je de jansko letno naxrpalo 1100 milijonov $\mathrm{m}^{3}$ oziroma $35.5 \mathrm{~m}^{3} / \mathrm{s}$ (1605 l/preb./dan), kar predstavlja že dobro cetrtino bilaněncga minimuma slovenskih rek, ki znasa $130 \mathrm{~m}^{3} / \mathrm{s}$ (Plut, 1987). Upoštevati pa je potrebno, da je bilo del tega $\left(80 \mathrm{~m}^{3} / \mathrm{s}\right)$ že sredi sedemdesetih let (zlasti vode Mure in Drave) zaradi onesnaženja neprimernih za uporabo brez predhodnjega ciscenja (Lah, 1977).

Med posameznimi fiziŁnogeografskimi potezami Slovenije je potrebno izdvojiti predvsem razčlenjenosti reliefa, zlasti v globoke, ozke doline ter kotline, ki skupaj s tem povezanimi klimatskini potczami vplivajo na nesorazmernost in moxno onesnaženost zrađnih plasti (Radinja, 1979). Raž̌lenjenost reliefa in poudarjena viß̌inska plastovitost na kratke razdalje vpliva na izredno prostorsko variabilnost samocistilnih sposobnosti. Razgibanost reliefa je torej osrednja fiziðnogeografska znacilnost, ki pogojuje fizixnogeografsko in ckolosko pestrost Slovenije. Pokrajinsko - ekoloska pestrost pokrajinskih elementov in pokrajinskih tipov, kjer se harmonično izmenjujejo gore, doline, moxvirja, jezera, reke, gozdovi, polja in travniki, pogojuje globalno ekolosko stabilnost slovenskih pokrajin (Slovenija - naSe okolje, 1976). Radinja (1988) ugotavlja, da so negativne posledice (npr. zakisanje okolja) zaradi zelo visoke kolicine padavinskega žvepla v Sloveniji neprimerno manjక̌e kot bi priðakovali glede na prejeto kolixino na povrß̌insko enoto. Predvasem pretežno karbonatna sestava Slovenije skupaj z nekaterimi drugimi pokrajinskimi potezami posredno ali neposredno nevtralizira zakisanje okolja., zlasti prsti in vode. Vendar se na tovrstno toleranđnost nasega okolja ne kaže prevec zanašati že zaradi vse vexjjih posrednih in kumulativnih uxinkov (Radinja, 1988). Vendar je potrebno istođasno podertati, da npr. globalna ekolo§ka stabilnost ne izkljuxuje tudi sezonsko zmanjక̌anih samoregeneracijskih in degradacijskih zmogljivosti za posamezne degradacijske procese oziroma oblike onesnaženja. To کe posebej velja za slovenske a!pske in predalpske kotline in doline ter kraska polja, ki v zimski polovici leta postanejo zračno zaprti pokrajinski sistemi, z narašajočo onesriaženost jo zraka, ki degradacijsko vpliva na druge pokrajinotvorne poteze. $\mathrm{Na}$ drugi strani pa prav tako odprtost in tranzitnost pokrajinskih potez Slovenije povzroca, da sprejme, transformira in oddaja degradacijske snovno - energetske prilive in odlive (onesnažene zračne mase, onesnažene tekołe vode). Navedeni primeri nazorno poderrtujejo nujnost vsestranskega ovrednotenja pokrajinotvornih elementov in pokrajinskih sistemov Slovenije, ki lahko pospesujejo ali omilijo degradacijske procese. Vsestransko proucevanje pokrajinskih tipov je ena izmed osnov za načrtovanje tudi pokrajinsko-ekolosko pretehtanega, uravnovełenega gospodarskega razvoja.

Prostorsko izrazita variabilnost fizienogeografskih in družbenogeografskih znacilnosti se kaže v pokrajinskih tipih, pokrajinskih in regionalnih ekosistemih Slovenije, ki se razlixno odzivajo na strukturo in dinamiko degradacijskih procesov. Procesi poeno- 
stavljanja mozaiðne pokrajinsko - ekološke sestavine Slovenije s pozidavami, hidromelioracijami, regulacijami vodnih tokov, monokulturami in drugimi antropogenimi posegi bistveno slabijo samoregulacijske zmogljivosti. Doloceni biotopi so izredno ogroženi (npr. vlažna obmoxja), s tem pa tudi mnoge rastlinske in živalske vrste, ki so del narodne identitete ter naravne dediš̌ine slovenskega prostora. Po Rdeð̌emu seznamu ogroženih praprotnic in semenk je okoli $12 \%$ ( 342 taksonov) slovenske flore ogroženih, 31 rastlin od tega pa je že izumrlo (Wraber - Skoberbne, 1989).

Splošna družbeno - politiðna kriza, klavrn in kritiðen gospodarski položaj, izそrpani naravni viri, kemizacija in degradacija okolja, so osnovni vzroki za pospešeno in neobhodno iskanje prostorsko-ekološko sprejemljivejšcga modela razvojnih strategij. Slovenija se torej s posledicami polucijskega zgostitvenega stresa sređuje v skrajno neugodnem trenutku: izěrpani naravni viri in populacijski viri, surovinsko-energetska zahtevna industrijska struktura, pomanjkanje inovativnih razvojnih programov in znanja ter nerazvita materialna infrastruktura. Zaradi pozidave in zarašanja je bilo $v$ letu 1986 na prebivalca Slovenije na razpolago le కe $3265 \mathrm{~m}^{2}$ obdelovalnih povr $\aleph_{\text {in }}$ oziroma $1253 \mathrm{~m}^{2}$ njiv in travnikov, kar je pod strateškim minimumom (Lah, 1989).

Pokrajinska obremenitev in onesnaženost okolja je zlasti v osemdesetih letih pricela dobivati vse boij jasne negativne razsežnosti v ekonomskem pogledu. Družbeni proizvod in narodni dohodek, pridobljen z ekstenzivno rabo surovin in energije na racun degradacije okolja, je pricel zaostajati. Primerjava koeficienta med narodnim dohodkom na prebivalea (1984) in polucijsko obremenitvijo $\left(\mathrm{SO}_{2}\right.$ in organsko onesnaževanje voda v PE) po obxinah Slovenije kaže (karta), da med obema spremenljivkama ne obstaja velika stopnja povezanosti. Tako se $\mathrm{v}$ skupino ob $x_{i n} \mathrm{z}$ najbolj neugodnim razmerjem uvrక̌̌ajo pretcžno obð̌ine $\mathrm{z}$ nižjim ali stagnirajočim narodnim dohodkom na prebivalca (Ptuj, Murska Sobota, Ljutomer, Gornja Radgona, Laško, Zagorje, Hrastnik, Trbovlje, Trebnjc). Gospodarsko usmeritev v pokrajinsko in energetsko surovinsko zahtevne proizvodnje (metalurgija, rudarstvo, TE, prehrambena in papirna industrija, prašǐje farme itd.) prinaక̌a tudi vse manjక̌e ekonomske uxinke.

Pod pritiskom javnosti spremenjen dolgoroðni prostorski pian Slovenije (1985 - 2000) sicer prinaక̌a sprejemljivejšo, tržno naravnano razvojno usmeritev, ki pa కe vedno sloni na kolixinskih kazaicih razvoja. Obstaja upraviæena bojazen, da bodo sicer potrebni in predvideni sanacijsko - kurativni ukrepi (očžveplevanje na TE, cistilne naprave za odpadne vode naselij, nadzorovano odiaganje posebnih in komunalnih odpadkov) nezadovoljivi zaradi dodatnih polucijskih obremenitev, zanemarjanja ekonomskih vzpodbud zmanjševanja onesnaževanja ter pravnih ukrepov za ostrejse in dosledno kaznovanje onesnaževalcev. Cilj "zelene", tudi ekonomsko in socialno uspeకñe razvojne strategije Slovenije naj bi bilo el:cloško strukturirano gospodarstvo in nax̌in življenja, prilagojen spccifiěnemu prostorsko - ekološkemu in poselitevene- 
mu vzorcu ter skromnemu surovinsko - energetskemu potencialu posameznih slovenskih pokrajin (Tepina, 1986). Navedene omejitve in že dosežena zgostitev poselitve ravninskega sveta ne dopušxajo mox̌nejše regionalne zgostitve prebivalcev in onesnaževalcev, izgradnje velikih surovinsko - energetsko intenzivnih in entropijsko - onesnaževalnih industrijskih obratov, centraliziranih energetskih in prometnih objektov brez nepopravljive ekoloske, zdravstvene in $\mathrm{v}$ konæ̌ni fazi ekonomske §kode. Pokrajinska mozaixna sestava Slovenije in poselitveni vzorec z okoli 6000 pretežno manjšmi naselji (nad dve tretjini naselij imata manj kot 200 prebivalcev) omogođata policentriðni regionalni razvoj nižje hierarhije in decentralizirano industrializacijo $\mathrm{z}$ radikalno drugačnim odnosom do t.i. "stranskih" produktov dela in bivanja. Pospeševati je treba zlasti razvoj manjsih, fleksibilnih industrijskih objektov in proizvodnih celic, $\mathrm{ki}$ slonijo na lokalnih, regionalnih virih, znanju in okolju prijazni "mehki" tehnologiji z majhno porabo surovin in energije (Plut, 1987).

Razreševanje izredno zapletenih prostorsko - ekoloskih dilem moxno antropogeniziranih, zlasti dolinsko - kotlinskih pokrajinskih ekosistemov, ne more dolgorocno prenesti uspehov zgolj $\mathrm{z}$ rahlo spremembo dosedanjih trendov pretežno stihijske urbanizacije in ekstenzivne industrializacije, saj pomeni bližnjico v praktǐ̌no nerešljive, ireverzibilne, prostorsko ckoloske posledice. Stopnja degradacije antropogeno močno preoblikovanih obxutljivih pokrajinskih ekosistemov v Sloveniji kaže, da že dosedanja onesnaženost presega emisijske in samoregulativne zmožnosti, zato so s tega vidika nesprejemljive težnje $\mathrm{k}$ nadaljnji krepitvi vex jih prebivalstvenih zgostitev, nadaljn jega razvoja veleindustrije in novih centraliziranih energetskih objektov (zlasti TE in JE ter akumulacijskih HE). Razvojna strategija degradiranih, z onesnaženost jo obremenjenih in visoko cntropijskih obmoxij, bi morala biti prednostno usmerjena $\mathrm{v}$ preventivo, $v$ zmanjševanjc degradacije, $\mathrm{z}$ ekolosko ustreznim prestrukturiranjem obstoječc gospodarske sestave in usmeritve, preventivnih (sprememba tehnologije) in kurativnih (izgradnja cistilnih naprav) pri najvecjiih onesnaževalcih in podpiranje novih, alternativnih industrijsko - energetskih in urbanizacijskih usmeritev (proizvodne celice, $\mathrm{z}$ delom na domu, drobno gospodarstvo in obrt, rabo alternativnih in lokalnih ẹnergetskih virov, usmer janje urbanizacije v biižnja obrobja dolin in kotlin ter na manj kakovostna zemijisča s humano revitalizacijo mest itd.). Klemenčx (1986) s sodelavci ugotavija, da novejši razvoj tchnologije in informatike daje objektivne možnosti za dekoncentracijo industrije, organizacijo proizvodnih celic zunaj centrov zgostitve (npr. v Mežiß̌ki dolini - po posameznih kmetijah), upoštevati pa je potrebno vrsto prostorsko - ekoloskih omejitev.

Polucijsko obremenjene in gosteje naseljene dolinsko - kotlinske in moxno antropogenizirane pokrajinske tipe pa se dodatno (stanovanjsko, zaposlitveno, polucijsko) bremenijo doselitve iz robnih obmocij (kot posledica stihijske preslojitve), ki pa jih ni mogoce omejiti $\mathrm{z}$ administrativnimi ukrepi. Krepiti in družbeno podpreti je potrebno težnjo ostajanja prebivalcev hribovitih, obrobnih obmoxij tudi na racun večanja lo- 
kalne (proizvodne, oskrbne) avtonomnosti, razvijanja biodinamixnega kmetijstva, neagresivnega turizma in ohranjanja največje "naravne" dobrine Slovenije - zdrave, kulturne pokrajine.

Obseg, intenzivnost in pokrajinsko - zdravstvene posledice narašajocih degradacijskih procesov v Sloveniji so bistveno veðji kot bi priðakovali po doseženem nivoju materialnega standarda. Slovenija je v primerjavi s sosednjimi, italijanskimi in avstrijskimi regijami gospodarsko možno zaostala in obdržala možne poteze klasið̌ne, surovinsko-energetsko potratno zasnovane industrializacije. $Z$ visoko porabo primarne energije $(32.000 \mathrm{~kW})$ in elektrixne energije $(5.000 \mathrm{~kW})$ na prebivalca ustvari $2-3 \mathrm{krat}$ manjßi dohodek na enoto porabljene energije kot regije Zahodne Evrope. Uvrštamo se med energetsko neuðinkovite dežcle, relativno energetsko neodvisno podroðju clektriðne energije pa plačujemo $z$ izredno energetsko nepogojeno degradacijo okolja (Novak, 1989). Neobhodno prestrukturiranje ekstenzivnega gospodarstva ima torej tako ekonomske kot ekološke prednosti. V pokrajinsko mozaixni in miniaturni Sloveniji predstav!ja poseben problem JE Krß̌o in Rudnik urana Žirovski vrh, skupaj z nerešenim vprašanjem odlaganja nizko, srednje in visoko radioaktivnih odpadkov.

Ncobhodno je: a) premisljeno in vztrajno rescvanje in

b) takojšnjc ter učinkovito prepređevanje nastanka novih virov onesnaževanja.

Doloðen , zmeren optimizem glede reševanja pereð̌e ekonomsko - ckološke krize vnǎ̌a prehajanje $v$ tržno ekonomijo, prilagajanje emisijskih in imisijskih standardov Evropi 92, krepitev elementov politixnega pluralizma in ekološkega gibanja kot sredstva javnega pritiska. Ekolosko zaostrena zakonodaja je obenem tudi predpogoj za legitimen pritisk, da ekonomski cilji razvoja ne bodo doseženi z nadaljnjim stopnjevanjem pokrajinske degradacije ter $\mathrm{z}$ uvozom umazanih tehnologij. Geografsko in glede degradacijskih procesov tranzitna Slovenija (voda, zrak) je takorekoz prisiljena iskati lokalno, regionalno in mednarodno sprejem!jivo ter optimalno razvojno usmeritcv. S končno praktix̌no uveljavitvijo civilizacijsko odigovornega spoznanja, da je varovanje okolja in naravnih virov obvezen roben pogoj gospodarjenja, organsko prostorska sestavina కirకe pojmovanega napredka, kvalitete življenja in osnova preživetja, ne pa nadležen in "nepotreben" zaviralen element. Zlasti v regiji, kjer zahtevajo degradacijski procesi že obฮ̌utne, ekolǒ̌ke, zdravstveno - ckonomske žrtve in pospeకeno izumiranje rastlinskih in živalskih vrst. Zato je ob menjajoðem se odnosu prebivalcev Slovenije do okolja tudi ekološko lahko uspešna le $z$ dolgorozno uspešno in optimalno (namesto maksimalne) ekosistemsko razvojno usmeritvijo, temeljita in pogosto boleca prenova slovenskega gospodarstva s spremenjeno proizvodno sestavo, življenjskimi navadami in drugacno lestvico vrednot, $z$ jasno opredeljeno in organsko vgrajeno kurativno in preventivno ekolosko politiko. 


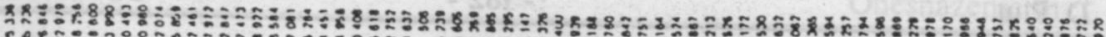

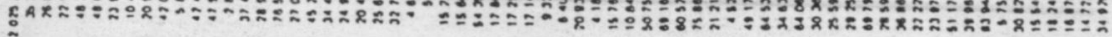

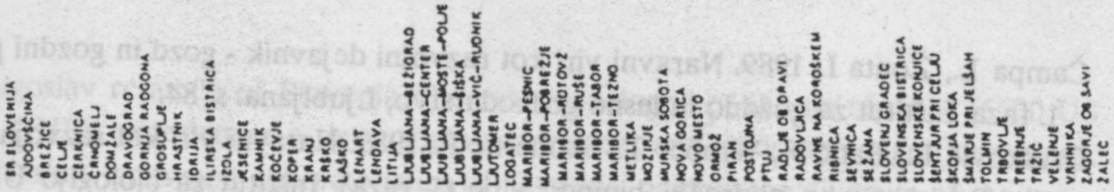

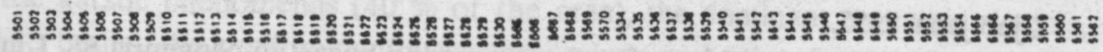

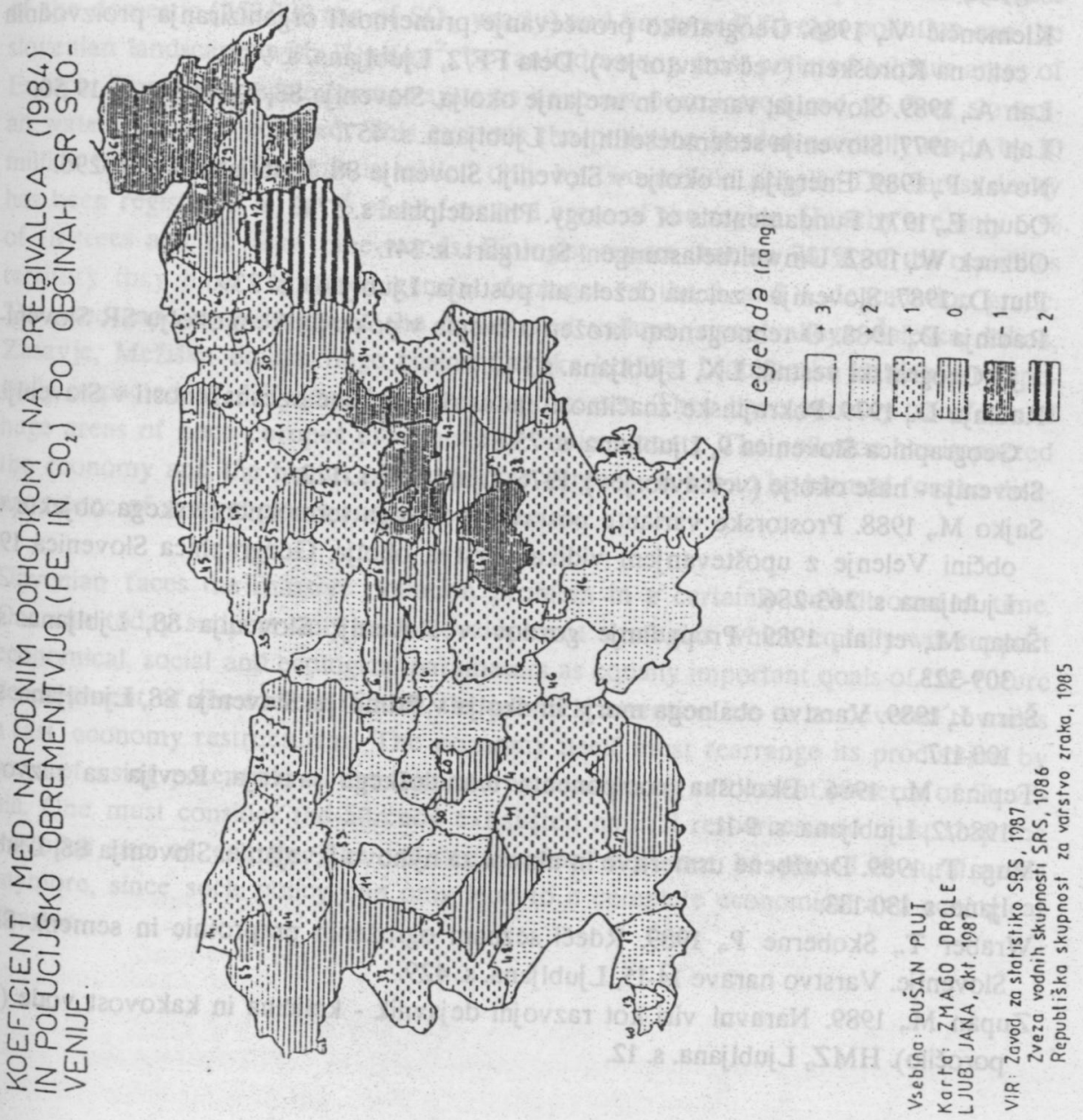




\section{LITERATURA}

Čampa L., Žonta I., 1989. Naravni viri kot razvojni dejavnik - gozd in gozdni prostor, 1. faza. Inštitut za gozdno in lesno gospodarstvo, Ljubljana. s. 84.

Druškovið B., Batið F., Wraber T., Skoberne P., 1989. Naravni viri kot razvojni dejav. nik, Raziskava na podroxju bioindikacije (1. faza). Institut za biologijo Univerze, Ljubljana. s. 55.

Habix P., 1989. Slovenski kras in njegovo vodno bogastvo. Slovenija $88, \mathrm{~L}$ jubljana. s. 89-94.

Klemencix V., 1986. Geografsko prouðevanje primernosti organiziranja proizvodnih celic na Koroß̌kem (vex soavtor jev). Dela FF/2, Ljubljana. s. 98.

Lah A., 1989. Slovenija; varstvo in urejanje okolja. Slovenija 88, L jubljana. s. 19-50.

Lah A., 1977. Slovenija sedemdesetih ict. Ljubljana. s. 457.

Novak P., 1989. Energija in okolje v Sloveniji. Slovenija 88, Ljubljana. s. 280-296.

Odum E., 1971. Fundamentals of ecology. Philadelphia. s. 574.

Odzuck W., 1982. Umweltbelastungen. Stuttgart. s. 341.

Plut D., 1987. Slovenija - zelena dežela ali pustinja. Ljubljana. s. 239.

Radinja D., 1988. O tehnogenem kroženju žvepla v pokrajinskem okolju SR Slovenije. Geografski vestnik LX, L jubljana. s.3-19.

Radinja D., 1979. Pokrajinske znaxilnosti industrializacijske onesnaženosti v Sloveniji. Geographica Slovenica 9, L jubljana. s. 75-84.

Slovenija - naše okolje (ve` avtorjev), 1976. Ljubljana. s. 122.

Sajko M., 1988. Prostorske variante postavitve novega termoenergetskega objekta v ob $x_{i n i}$ Velenje $z$ upostevanjem vidika varstva okoija. Gcographica Slovenica 19, Ljubljana. s. 263-286.

Šolar M., et al., 1989. Propadanje gozdov v Sloveniji. Slovenija 88, Ljbljana. s. 309-323.

Štirn J., 1989. Varstvo obalnega morja in okolja v Primorju. Slovenija SS, Ljubljana. s. 100-117.

Tepina M., 1986. EkoloSka komponenta tehnoloßkega razvoja. Revija za razvoj, 1986/2, Ljubl jana. s. 9-11.

Vuga T., 1989. Družbene usmeritve in ukrepi za njihovo izvajanje. Slovenija 88 , Ljubljana. s. 130-133.

Wraber T., Skoberne P., 1989. Rdeci seznam ogroženih praprotnic in semenk SR Slovenije. Varstvo narave 14-15, Ljubljana. s. 429.

Zupan M., 1989. Naravni viri kot razvojni dejavnik - kolizina in kakovost vode (1. poroxilo). HMZ, L jubljana. s. 12. 


\section{POLLUTION AND THE REGIONAL DEVELOPMENT OF SLOVENIA}

The Yugoslav republic of Slovenia, the most deveioped of the six republic (5500 US Dollars GNP), experiences a deep socio-economical and landscape-degrational crisis. The different landscape characteristics of Slovenia, namely the diversity of the topography, the karstic phenomenas ( $40 \%$ of the area), the dominant mountain sistems, valleys and basins, the predominantly westerly winds and other features impact and extend in different ways the area and the intensity of degradation processes. Because of the domestic ( 250.000 ton of $\mathrm{SO}_{2}$ yearly) and "imported" foreign pollution can the siovenian landscape, with $11 \mathrm{~g} / \mathrm{s} / \mathrm{m}^{2}$, be ranked among most polluted sulphur areas of Europe. Since large scale sewage systems have not been introduced, $96 \%$ of slovenian waters are also polluted. This exceeds the pollution burden normally made by 10 million inhabitants. Slovenia is settled only by two million people. The forest decay has been registered in $44 \%$ of all forested areas of the region. Healthy are only $6 \%$ of fir-trees and $22 \%$ of pine-woods. Biologist report that on $70 \%$ of the republics territory they have registered genetic damages of the 3. and 4. degradation grade. The landscape ecosystems of the basins and valleys (river valleys: Šaleška dolina, Zasavje, Mežiška dolina; huge basins: Celjska kotlina, Ljubljanska kotlina) are specially impacted by different degradation processes. They have allready transformed huge areas of once europes most healthy environments. The pollution has impacted the economy and the health of the people allready. It has to be blamed for the disappearance of several plants and animal species.

Slovenian faces the massive pollution problem in a certainly unwellcommed timie. One can today support only such development strategies which equally will support economical, social and ecological parameters as equally important qoals of the future development of the society. Today, the primarly attention has to be devoted towards a fast cconomy restructuring. The economy itself must rearrange its production by ways of using potentials of the area and by considering settlement patterns of Slovenia. One must consider the allready exhausted natural resources and must stop the wastefull use of energy. The industrialisation must not be placed in rural areas anymore, since such policy can only lead to a complete economical and ecological disaster. 
$\mathrm{K}-2$

OGROŻENOST ORE VESNIH VRST (vSe vrste skupaj $v *$ )

PO GG OBMOĆJH

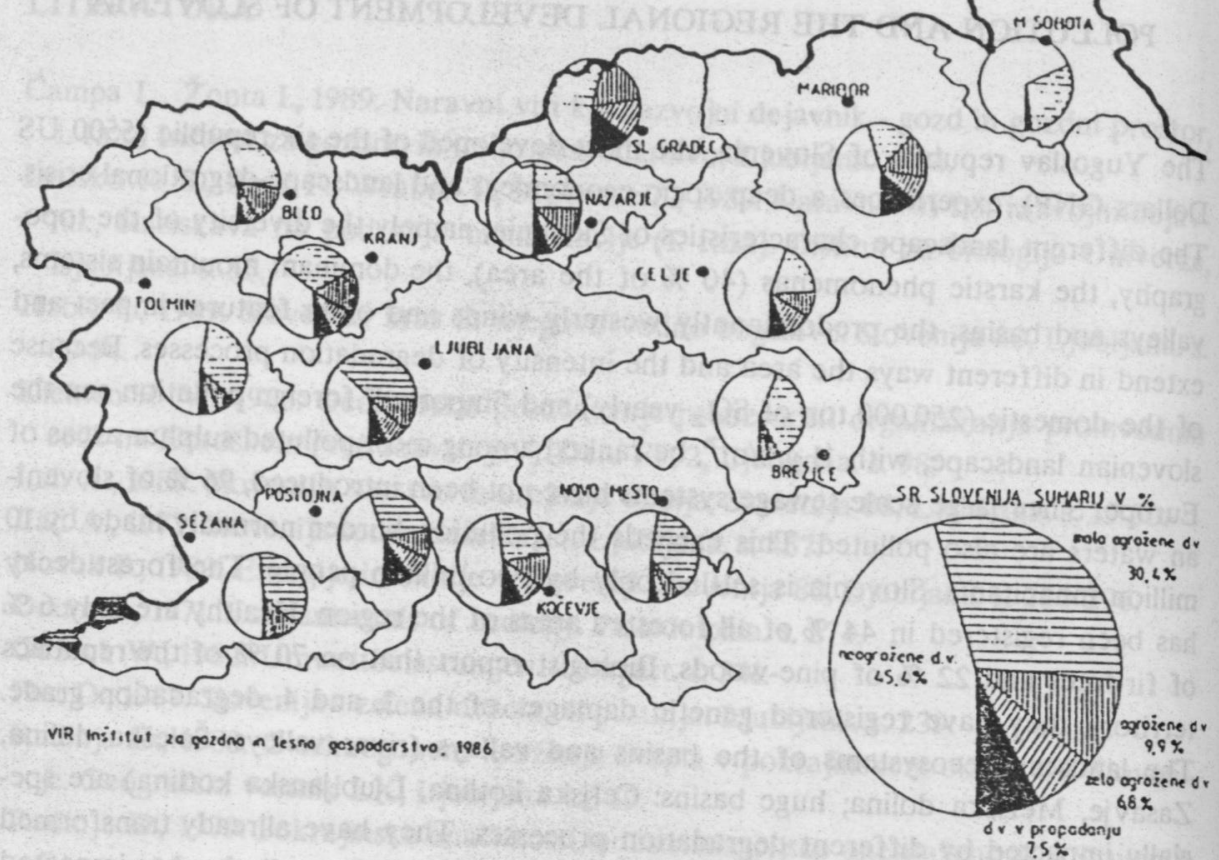

K-1

ONESNAZEENOST ZRAKA $\vee$ SR SLOVENIJI

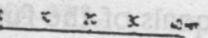
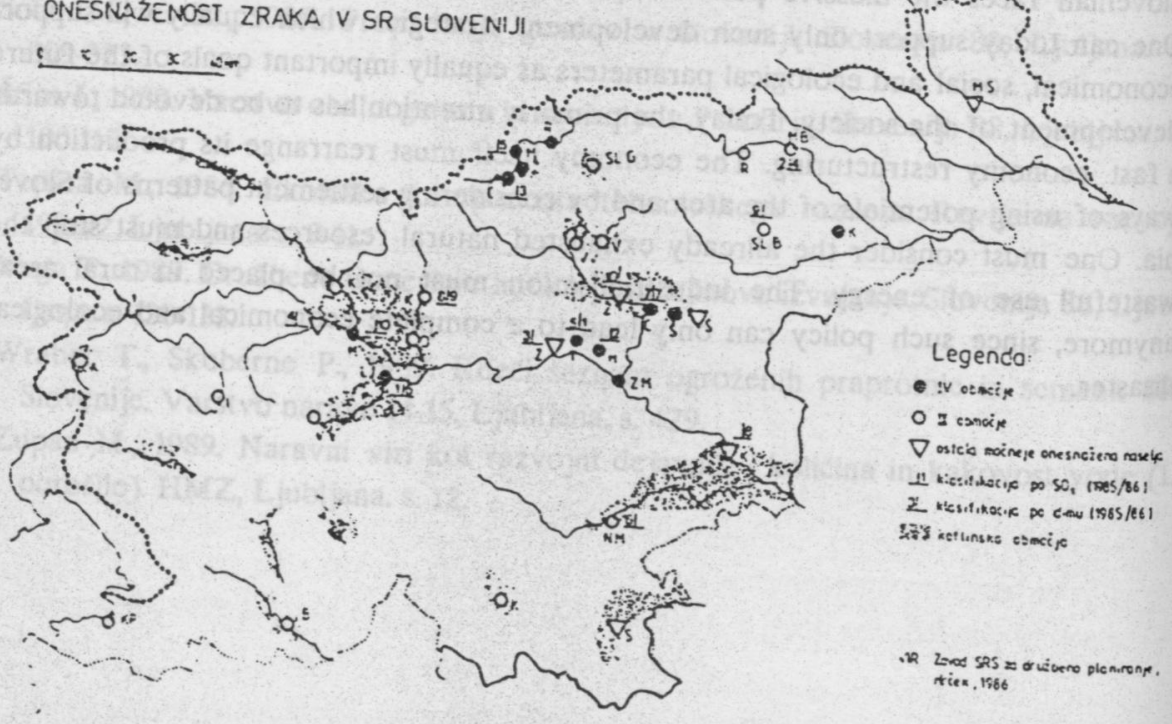